\title{
A Continuous Method for the Estimation of Adenosine Deaminase Catalytic Concentration in Pleural Effusions with a Hitachi 705 Discrete Analyser
}

\author{
By E. H. Slaats, E. G. M.Th. Asberg
}

Department of Clinical Chemistry

A. R. J. van Keimpema

Department of Pulmonary Diseases and

H. Kruijswijk

Department of Clinical Chemistry, Hospital "Onze Lieve Vrouwe Gasthuis", Amsterdam, The Netherlands

(Received April 24/June 14, 1985)

\begin{abstract}
Summary: An assay of adenosine deaminase activity in pleural effusions is described. For the continuous determination of adenosine deaminase, the liberated ammonia is estimated by coupling the liberated $\mathrm{NH}_{3}$ with 2-oxoglutarate. The reaction is followed by the decrease of NADH absorbance at $340 \mathrm{~nm}$. The assay was optimized for a Hitachi 705 analyser, with respect to $\mathrm{pH}$, adenosine concentration and glutamate dehydrogenase activity. The assay is linear to an adenosine deaminase catalytic concentration of $110 \mathrm{U} / \mathrm{l}$. Elevated adenosine deaminase activities are found in pleural effusions of patients with tuberculosis, empyema and mesothelioma. Although elevated adenosine deaminase activity in pleural effusion is not pathognomonic for tuberculosis, it may be valuable as a first screening parameter.
\end{abstract}

Eine Methode zur kontinuierlichen Messung von Adenosindesaminase in Pleuraexsudaten mit dem diskreten Analysator Hitachi 705

Zusammenfassung: Eine Bestimmungsmethode für Adenosindesaminase in Pleuraexsudaten wird beschrieben. Zur kontinuierlichen Bestimmung von Adenosindesaminase wird das freigesetzte Ammoniak mit 2-Oxoglutarat umgesetżt. Die Reaktion wird durch Messung des NADH-Verbrauchs bei $340 \mathrm{~nm}$ kontinuierlich verfolgt. Die Methode wurde hinsichtlich pH, Adenosinkonzentration und katalytischer Konzentration von Glutamatdehydrogenase für den Hitachi 705 optimiert. Die Methode ist linear bis 110 U/l Adenosindesaminase. Erhöhte katalytische Konzentrationen werden in Pleuraexsudaten bei Tuberkulose, Empyem und Mesotheliom gefunden. Obwohl die erhöhte Adenosindesaminase nicht pathognomonisch für Tuberkulose ist, kann sie als ein erstes Merkmal für das Screening wertvoll sein.

\section{Introduction}

Adenosine deaminase (EC 3.5.4.4) is a widely distributed enzyme, which catalyses the hydrolysis of adenosine to inosine and ammonia in the purine catabolic pathway. Adenosine deaminase is essential for the differentiation of lymphoid cells, particular $T$ cells (1) and maturation of monocytes to macrophages (2). Its deficiency in the lymphocytes results in severe combined immunodeficiency disease $(3,4)$. Elevated adenosine deaminase activity is found in 
serum of patients with infectious mononucleosis (5), acute leukaemia (8), typhoid fever (6), liver diseases $(7,10)$ and sarcoidosis (18). In pleural effusions of patients with tuberculosis, empyema and rheumatoid pleural effusion, higher adenosine deaminase activities are reported than in malignant or parapneumonic pleural effusions $(9-13)$. The adenosine deaminase activity may be measured by determination of the rate of either consumption of adenosine or of formation of inosine or ammonia. The determination of produced ammonia is mostly used in routine measurements. The ammonia can be determined by the indophenol reaction (Berthelot) $(14,15)$ or by coupling the liberated $\mathrm{NH}_{3}$ to 2-oxoglutaric acid with glutamate dehydrogenase (EC 1.4.1.3). The last method has the advantage that the overall reaction can be followed by the rate of consumption of NADH.

We have adapted this method for measurement with a Hitachi 705 discrete analyser, in order to study the usefulness of adenosine deaminase determination in the evaluation of the origin of pleural effusions.

\section{Materials and Methods}

Reagents

1. Phosphate buffer $0.25 \mathrm{~mol} / \mathrm{l} \mathrm{pH} \mathrm{7.5:}$ $39.0 \mathrm{~g} \mathrm{Na}_{2} \mathrm{HPO}_{4} \cdot 2 \mathrm{H}_{2} \mathrm{O}, 4.2 \mathrm{~g} \mathrm{KH}_{2} \mathrm{PO}_{4}$ in 1 litre distilled water.

2. Adenosine (Boehringer Mannheim, FRG) $300 \mathrm{mmol} / \mathrm{l}$ ): suspend $2.0 \mathrm{~g}$ in $20 \mathrm{ml}$ distilled water and add dropwise 360 $\mathrm{g} / \mathrm{kg} \mathrm{HCl}$ until the adenosine is dissolved. Adjust to $25 \mathrm{ml}$ with distilled water. Stable for 1 month at $-20^{\circ} \mathrm{C}$.

3. Glutamate dehydrogenase in glycerol, $1200 \mathrm{kU} / \mathrm{l}$ (Boehringer Mannheim, FRG, 127710).

4. 2-Oxoglutaric acid (Boehringer Mannheim, FRG) $0.2 \mathrm{~mol} / \mathrm{l}$ : dissolve $2.9 \mathrm{~g}$ in $100 \mathrm{ml}$ distilled water and neutraliže. Stable for 1 month at $-20^{\circ} \mathrm{C}$.

5. NADH, disodium salt (Boehringer Mảnnheim, FRG, Grade I), $\pm 21 \mathrm{mmol} / \mathrm{l}:$ dissolve $15 \mathrm{mg} / \mathrm{ml}$ distilled water. Prepare fresh daily.

6. ADP, disodium salt (Boehringer Mannheim, FRG) 90 $\mathrm{mmol} / \mathrm{l}$ :

dissolve $425 \mathrm{mg}$ ADP in $10 \mathrm{ml}$ distilled water.

In the final reagent $15 \mathrm{ml}$ phosphate buffer is mixed with 300 $\mu l$ glutamate dehydrogenase suspension, $200 \mu \mathrm{l}$ 2-oxoglutaric acid solution, $250 \mu \mathrm{l}$ NADH solution, $300 \mu \mathrm{l}$ ADP solution and $1250 \mu \mathrm{l}$ adenosine solution. The $\mathrm{pH}$ is adjusted to $7.25 \pm$ 0.05 . The final concentrations of the reagents are given in table 1.

The unspecific activity is measured under the same conditions with buffer instead of adenosine in the final reagent.

Tab. 1. Final concentrations of reagents.

\begin{tabular}{|c|c|c|c|}
\hline \multirow{2}{*}{\multicolumn{2}{|c|}{ pH }} & \multirow{2}{*}{\multicolumn{2}{|c|}{$\begin{array}{c}7.20-7.30 \\
0.22 \mathrm{~mol} / 1\end{array}$}} \\
\hline & & & \\
\hline $\begin{array}{l}\text { Adenosine } \\
\text { Glutamate dehydrogenase }\end{array}$ & & 21 & $\mathrm{kU} / \mathrm{l}$ \\
\hline 2-Oxoglutaric acid & & 2.3 & $\mathrm{mmol} / \mathrm{l}$ \\
\hline NADH & .1 & 0.3 & $\mathrm{mmol} / \mathrm{l}$ \\
\hline ADP & & 1.5 & $\mathrm{mmol} / \mathrm{l}$ \\
\hline
\end{tabular}

\section{Samples}

The pleural effusions were centrifugated at $1000 \mathrm{~g} 15 \mathrm{~min}$ and stored at $-20^{\circ} \mathrm{C}$ until assayed. The adenosine deaminase activity was unaltered for at least 4 months at $-20^{\circ} \mathrm{C}$.

No difference was found between serum, heparin plasma and EDTA plasma. Haemolytic samples with a concentration up to $0.24 \mathrm{mmol} / \mathrm{l}$ haemoglobin have no effect on the adenosine deaminase activity (tab. 2).

Tab. 2. Influence of haemolysis on the adenosine deaminase activity in serum at $37^{\circ} \mathrm{C}$

\begin{tabular}{ll}
\hline & $\begin{array}{l}\text { Adenosine deaminase } \\
(\mathrm{U} / \mathrm{l})\end{array}$ \\
\hline Serum & 23.5 \\
$+0.08 \mathrm{mmol} / \mathrm{l}$ haemoglobin & 22.9 \\
$+0.12 \mathrm{mmol} / \mathrm{l}$ haemoglobin & 23.9 \\
$+0.24 \mathrm{mmol} / \mathrm{l}$ haemoglobin & 23.3 \\
\hline
\end{tabular}

\section{Procedure}

The Hitachi 705 discrete analyser (Boehringer Mannheim, FRG) was operated according to the usual protocol, the settings being shown in table 3. The optimazation of the continuous method was performed on an Acta II spectrophotometer (Beckman Instr., NY, USA).

The molar lineic absorbance, $\varepsilon=622 \mathrm{~m}^{2} / \mathrm{mol}$ at $340 \mathrm{~nm}$, was used for NADH. With a reference wavelength of $660 \mathrm{~nm}$ on the Hitachi 705 discrete analyser, the molar lineic absorbance, $\varepsilon 340 / 660$ of $589 \mathrm{~m}^{2} / \mathrm{mol}$ was used.

The activity in $\mathrm{U} / 1$ is defined as the quantity of $\mathrm{NH}_{3}$ produced in $\mu \mathrm{mol}$ per minute per litre.

Tab. 3. Parameter listing for determination of adenosine deaminase activity at $37^{\circ} \mathrm{C}$ on a Hitachi 705 discrete analyser.

Assay code

Sample volume

$R_{1}$

$\mathbf{R}_{2}$

Wavelength 1

Wavelength 2

Factor

Abs. limit rate

2 (rate)-20-28
$20 \mu \mathrm{l}$
$350 \mu \mathrm{l}$
0
$660 \mathrm{~nm}$
$340 \mathrm{~nm}$
3161
$2000(0.2 \mathrm{~A})$

$20 . \mu l$

$350 \mu \mathrm{I}$

$340 \mathrm{im}$

$2000(0.2 \mathrm{~A})$ 


\section{Results}

pH-optimum

To determine the optimal $\mathrm{pH}$ for the assay, phosphate buffers ranging in $\mathrm{pH}$ from 6.9 to 7.5 are used. An optimal $\mathrm{pH}$ for the enzyme activity in the final reagent was found between 7.1 and 7.3 (fig. 1). In the final procedure a final $\mathrm{pH}$ of $7.25 \pm 0.05$ was chosen.

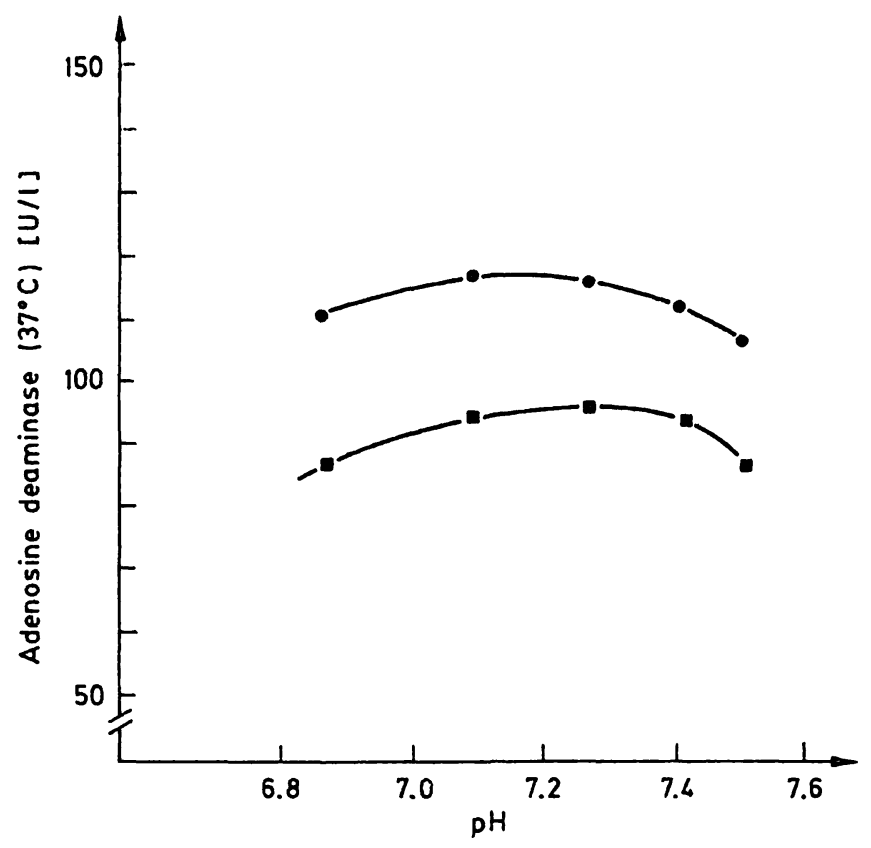

Fig. 1. Influence of $\mathrm{pH}$ on the adenosine deaminase activity in pleural effusion ( $(0)$ and serum ( $a)$.

\section{Optimal concentration of reagents}

The reaction time in the assay is limited by the use of the Hitachi 705 analyser, the measurement has to be completed within 10 minutes. As the endogenous ammonia and other substrates causing non-specific NADH consumption are eliminated within \pm 6 minutes, there is a period in which the decrease of the absorbance each 20 seconds can be measured and the linearity of the assay can be controlled. In figure 2 the rate of ammonia consumption is plotted as a function of the glutamate dehydrogenase activity. A glutamate dehydrogenase activity of $20 \mathrm{kU} / \mathrm{l}$ in the presence of $1.5 \mathrm{mmol} / 1 \mathrm{ADP}$ and $4 \mathrm{mmol} / \mathrm{l} 2$-oxoglutarate is sufficient to eliminate $700 \mu \mathrm{mol} / \mathrm{l} \mathrm{am}$ monia within 6 minutes. ADP in a concentration of $1.5 \mathrm{mmol} / 1$ is added to activate the glutamate dehydrogenase, according to the literature (16).

The adenosine concentration is varied between 5 and $27 \mathrm{mmol} / \mathrm{l}$. The influence of the adenosine concentration on the adenosine deaminase activity is given in figure 3. From a Lineweaver-Burk plot a Michaelis constant $\left(K_{\mathrm{m}}\right)$ is calculated: $K_{\mathrm{m}}=4.8$

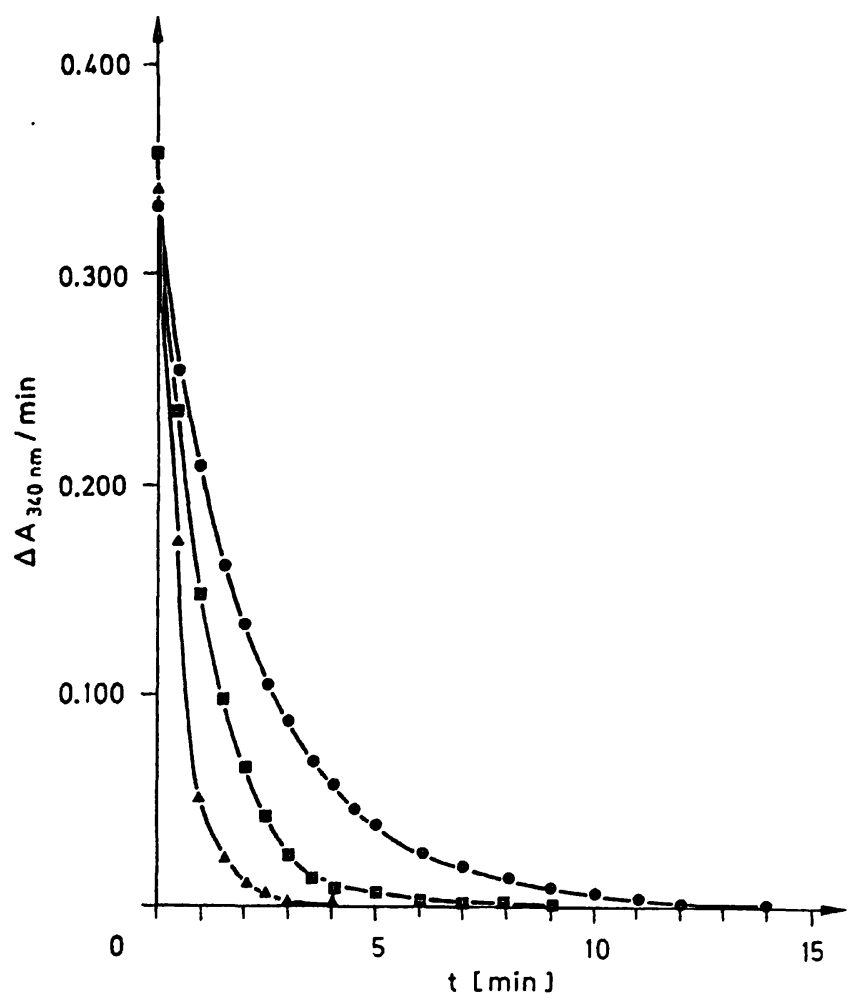

Fig. 2. Consumption rate of $\mathrm{NH}_{3}(700 \mu \mathrm{mol} / \mathrm{l})$ as function of the glutamate dehydrogenase activity at $37^{\circ} \mathrm{C}: 11 \mathrm{U} / \mathrm{l}$ (๑), $22 \mathrm{U} / \mathrm{l}(\boldsymbol{a}), 44 \mathrm{U} / \mathrm{l}(\Delta)$.

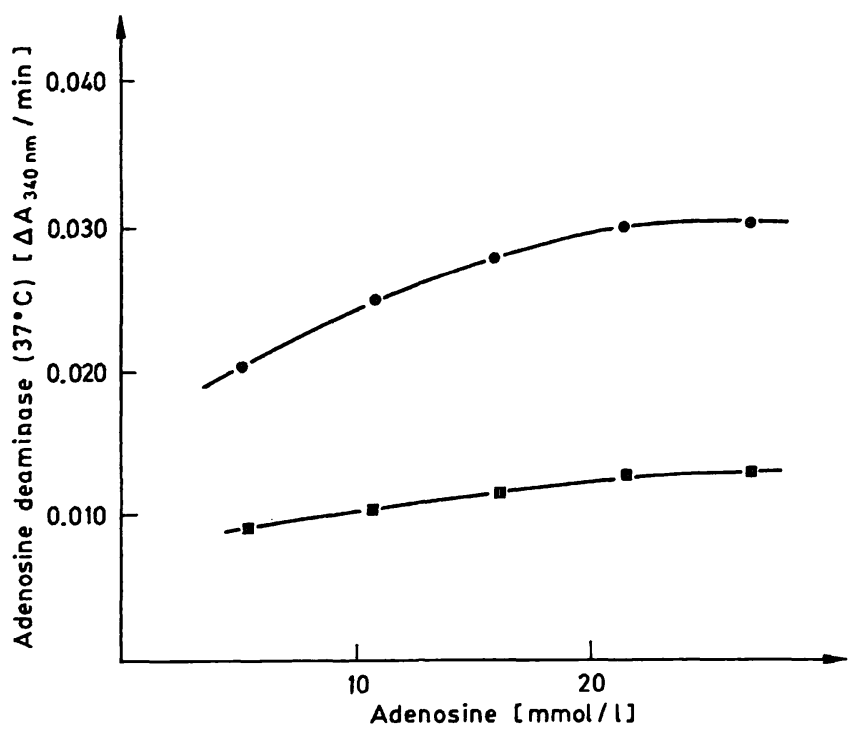

Fig. 3. Influence of the adenosine concentration on the adenosine deaminase activity in pleural effusion $(\Theta)$ and serum (घ).

$\mathrm{mmol} / \mathrm{l}$ in pleural effusion from tuberculosis and $K_{\mathrm{m}}=$ $3.4 \mathrm{mmol} / 1$ in a serum, thereby demonstrating the presence of various isoenzymes $(4,14)$. At a final adenosine concentration of $21.4 \mathrm{mmol} / \mathrm{l}$, the adenosine deaminase activities are $86 \%$ and $89 \%$ of $V_{\max }$ for the pleural effusion and serum, respectively. Higher adenosine concentration in the final reagent are not used because the adenosine tends to crystallize out. 


\section{Linearity}

The upper limit of enzyme activity at which a linear response can be obtained is determined by using mixtures of pleural effusions with a low adenosine deaminase level (sample A: $11 \mathrm{U} / \mathrm{l}$ ) and a high adenosine deaminase level (sample B: $1.84 \mathrm{U} / \mathrm{l}$ ). The fraction of pleural effusion $B$ in the mixture of pleural effusion $A$ and pleural effusion $B$ is given in figure 4. The calculated regression line is:

ADA (obs) $U / 1=173 \cdot$ fraction of sample $B+11.1$.

Using an upper limit of $110 \mathrm{U} / \mathrm{l}$ a correlation coefficient $r=0.9990$ is obtained.

\section{Precision}

The intra-run precision in the lower range is $2.4 \%$ $(\bar{x}=26.0, n=25)$ and in the elevated range $2.1 \%$ $(\overline{\mathrm{x}}=88.4, \mathrm{n}=25)$.

\section{Unspecific activity}

The unspecific activity in pleural effusions was measured in 119 patient samples. The mean activity was $4.6 \mathrm{U} / \mathrm{l}$ and the range $(\overline{\mathrm{x}} \pm 1.96 \sigma)$ is $0.2-9.5 \mathrm{U} / \mathrm{l}$. A maximal unspecific activity of $12.3 \mathrm{U} / \mathrm{l}$ was found.

\section{Adenosine deaminase in pleural effusions}

The adenosine deaminase activities among the various groups of lung diseases are compared in figure 5. The patients are subdivided into 5 groups:

I tuberculosis $(4 \times)$,

II empyema $(7 x)$,

III mesothelioma $(10 x)$,

IV other malignant neoplasms $(32 x)$,

$\mathrm{V}$ patients with pneumothorax $(9 \times)$, parapneumonic effusions $(14 \times)$, haematothorax $(2 \times)$, congestive heart failure $(2 x)$, and unspecific pleural effusions $(10 \times)$.

One patient in group V, with a Budd-Chiari syndrome with ascites, had an unspecific pleural effusion in which the adenosine deaminase activity was $81 \mathrm{U} / \mathrm{l}$. However, the adenosine deaminase activity in serum $(117 \mathrm{U} / \mathrm{l})$ was also elevated. No significant difference is found between group IV and V (Student t-test). From these two groups a distribution-free $98^{\text {th }}$ percentile of $44 \mathrm{U} / \mathrm{l}$ is found.

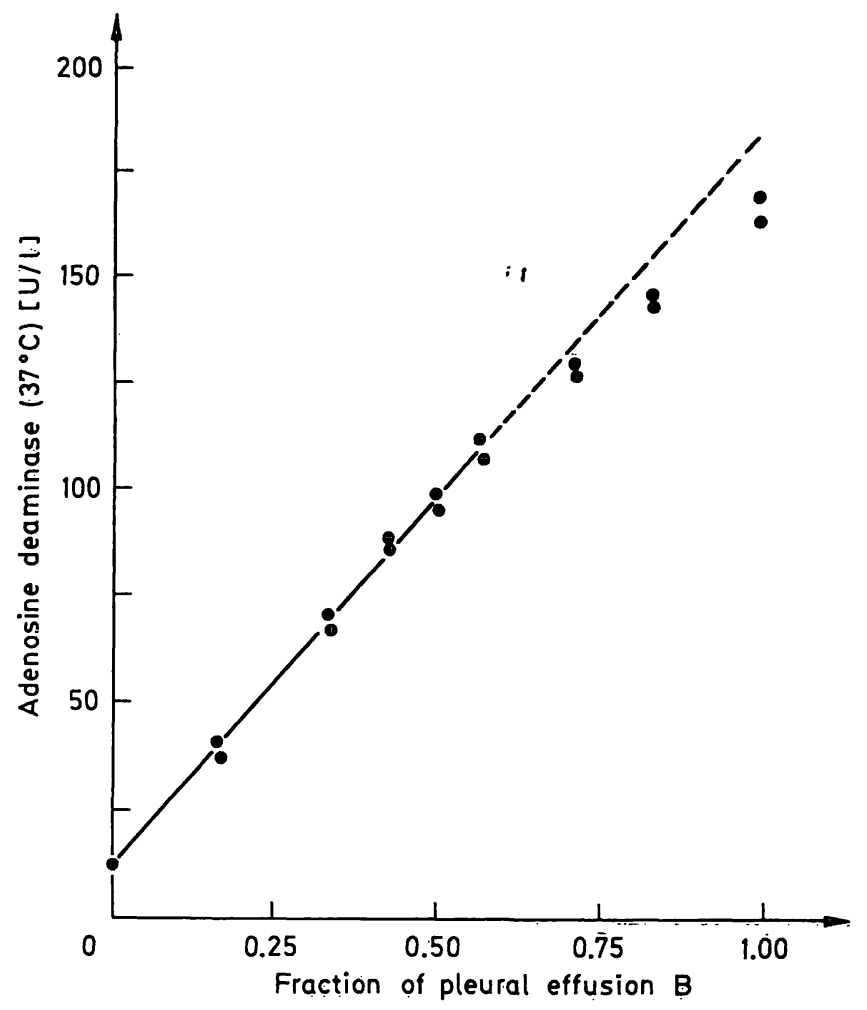

Fig. 4. Linearity of the adenosine deaminase assay. Pleural effusion B (184 U/l) is mixed with pleural effusion A (11 $\mathrm{U} / \mathrm{l})$.

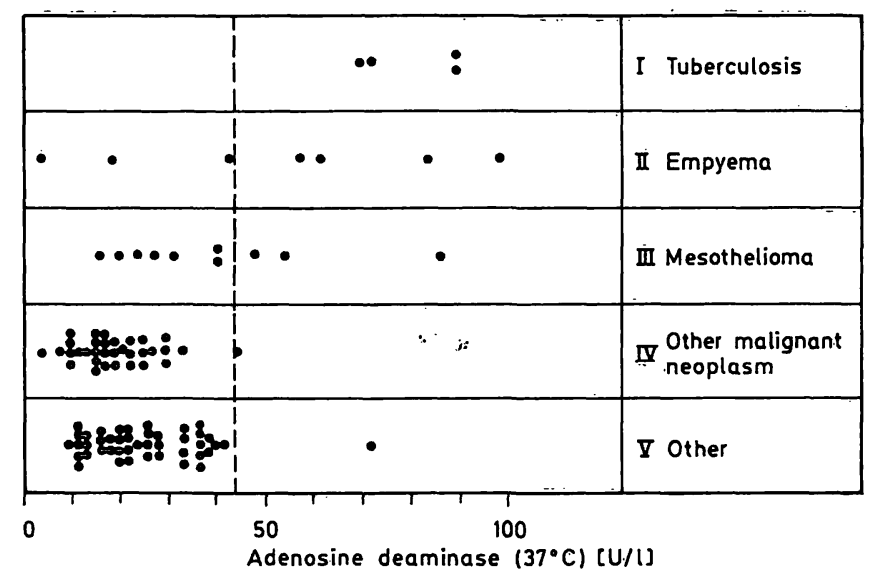

Fig. 5. Adenosine deaminase activity in pleural effusion in various disorders.

The line $(---)$ shows the $98^{\text {th }}$ percentile of group IV and V.

\section{Discussion}

Pleural effusions are frequently a diagnostic problem in clinical practice. A careful diagnostic evaluation of the aetiology of the effusion cannot be established in about $20 \%$ of patients (11). The estimation of adenosine deaminase in pleural effusions appeared to be a valuable aid in the diagnosis of tuberculous pleural effusions. Although the incidence of tuberculosis has decreased, this disease still has to be taken into account in the differential diagnosis of pleural effusions. 
Our intention was to look for a fast and simple test to make or exclude the diagnosis of tuberculosis, in order to avoid the necessity to prepare cultures for the identification of Mycobacterium tuberculosis, or to prepare biopsies of parietal pleura to look for epithelioid granulomas. The method for determination of adenosine deaminase activity by means of the Berthelot reaction $(11,15)$ is rather timeconsuming, therefore we adapted and optimized the enzymatic method for the estimation of the adenosine deaminase activity on a Hitachi 705 discrete analyser. The resulting enzymatic method gave a high quality performance.

Ratech \& Hirschhorn (4) have investigated the kinetic properties and molecular mass of the adenosine deaminase (ADA) isoenzymes. They reported a monomeric 35000 dalton isoenzyme $\mathrm{ADA}_{1}$, an 280000 dalton isoenzyme, containing 35000 dalton catalytic units with a nonenzymatic 200000 dalton combining glycoprotein $\mathrm{ADA}_{1, \mathrm{GP}}$ and a 100000 dalton isoenzyme $\mathrm{ADA}_{2}$. The reported $K_{\mathrm{m}}$ values for $\mathrm{ADA}_{1}$ and $A D A_{1, G P}$ are $51 \mu \mathrm{mol} / 1$ and $75 \mu \mathrm{mol} / 1$, respectively. For $\mathrm{ADA}_{2}, K_{\mathrm{m}}=2800 \mu \mathrm{mol} / \mathrm{l}$. Also the $V_{\max }$ values for $\mathrm{ADA}_{1}$ and $\mathrm{ADA}_{1, \mathrm{GP}}$ are more than 10 times less than that for $\mathrm{ADA}_{2}$.

Notably, a child with severe combined immunodeficiency (SCID), showed a complete absence of $\mathrm{ADA}_{1}$ and $\mathrm{ADA}_{1, \mathrm{GP}}$ in lymphocytes, erythrocytes and other tissues. The serum $\mathrm{ADA}_{2}$ activity was normal. These different kinetic properties of the adenosine deaminase isoenzymes are a confirmation of the work of Ellis \& Goldberg (16).

In tuberculous pleural effusion, we found a $K_{\mathrm{m}}$ of 4.8 $\mathrm{mmol} / \mathrm{l}$ for the adenosine deaminase enzyme. We were therefore probably dealing with the $\mathrm{ADA}_{2}$ type isoenzyme. For this reason, it becomes clear that the correlation with the number of lymphocytes in the pleural effusion, as sought by Petterson (17) and Ocana (12 a) will not be found; the lymphocytes contain only $\mathrm{ADA}_{1}$ type isoenzyme and in our and their assay the adenosine concentration is too high. At the adenosine concentration used, the conversion rate $V$ is about $88 \%$ of $V_{\max }$ for adenosine. With the large difference in $V_{\max }$ for the $\mathrm{ADA}_{1}$ type and $\mathrm{ADA}_{2}$ type isoenzyme (4), the $\mathrm{ADA}_{1}$ is obscured in a medium where $\mathrm{ADA}_{2}$ type enzyme is present in at least the same order of magnitude. Accordingly, and in contradiction with the literature $(10,15)$, our assay is not influenced by haemolysis. However, further study is necessary to clarify the origin and characterization of adenosine deaminase in tuberculous pleural effusions. Possibly the adenosine deaminase in tuberculous pleural effusions originates from the epithelioid granulomas.

Our clinical results are shown in figure 5. The diagnosis of tuberculosis was confirmed by culture.

There was no evidence of culture negative tuberculous pleural effusions in our population. From this small data group it appears that tuberculous pleural effusions have a significantly higher adenosine deaminase activity than pleural effusions of group IV and V (Student t-test, $\mathrm{p}<0.005$ ). With the exception of the results of Blake et al. (11), our results are in concordance with the literature (tab. 4). There is a discrepancy between the results of Blake et al. (11) and the other reported data (tab. 4). An explanation cannot be given, because Blake et al. give no specification of the used $\mathrm{pH}$, buffer concentration and glutamate dehydrogenase activity.

As can be seen from figure 5 , the adenosine deaminase activity in pleural effusions does not discriminate between tuberculosis, empyema and mesothelioma, when there is a normal blood level of adenosine deaminase activity. In the literature high values of adenosine deaminase activity are also described in pleural effusions from patients with rheumatoid arthritis (17). Consequently, elevated adenosine deaminase activity in pleural effusions is not pathognomonic for tuberculosis.

\section{Acknowledgement}

We gratefully acknowledge Dr. J. P. M. Wagenaar, head of the department of pulmonary diseases, and colleagues for providing several pleural effusions from patients.

Tab. 4. Reported adenosine deaminase activity in tuberculous pleural effusions at $37^{\circ} \mathrm{C}$

\begin{tabular}{|c|c|c|c|c|c|c|c|}
\hline Authors & Ref. & $\mathrm{n}$ & $\begin{array}{l}\overline{\mathrm{x}} \pm \sigma \\
(\mathrm{U} / \mathrm{l})\end{array}$ & $\begin{array}{l}\text { Obs. lower } \\
\text { limit } \\
(\mathrm{U} / 1)\end{array}$ & $\begin{array}{l}\text { Ref. } \\
\text { value } \\
(\mathrm{U} / \mathrm{l})\end{array}$ & Method & Year \\
\hline $\begin{array}{l}\text { Piras et al. } \\
\text { Blake \& Berman } \\
\text { Ocana et al. } \\
\text { Pelterson et al. } \\
\text { Present }\end{array}$ & $\begin{array}{l}(9) \\
(11) \\
(12 \mathrm{~b}) \\
(13) \\
-\end{array}$ & $\begin{array}{r}21 \\
82 \\
103 \\
14 \\
4\end{array}$ & $\begin{array}{r}83 \pm 26 \\
46 \pm 13 \\
91 \pm 29 \\
102 \pm 9 \\
80 \pm 10\end{array}$ & $\begin{array}{r}38 \\
5 \\
45 \\
52 \\
70\end{array}$ & $\begin{array}{l}<30 \\
<30 \\
<45 \\
<50 \\
<44\end{array}$ & $\begin{array}{l}\text { 1. c. }(15) \\
\text { GLDH/NADH } \\
\text { l. c. }(15) \\
\text { l.c. }(15) \\
\text { mod. l.c. (16) }\end{array}$ & $\begin{array}{l}1978 \\
1982 \\
1983 \\
1984 \\
1985\end{array}$ \\
\hline
\end{tabular}




\section{References}

1. Hovi, T., Smyth, J. F., Allison, A. C. \& Williams, S. C. (1976) Clin. Exp. Immunol. 23, 395-403.

2. Fisher, D. N., Van der Weyden, M. B., Snyderman, R. \& Kelley, W. N. (1976) J. Clin. Invest. 58, 399-407.

3. Giblett, E. R., Anderson, J. E., Cohen, F., Pollara, B. \& Meuwissen, H. J. (1972) Lancet II, 1967-1969.

4. Ratech, H. \& Hirschhorn, R. (1981) Clin. Chim. Acta 115, $341-347$.

5. Koehler, L. H. \& Benz, E. J. (1962) Clin. Chem. 8, $133-140$.

6. Giusti, G. (1970) Pol. Arch. Mew. Wewn. 44, 525.

7. Goldberg, D. M. (1965) Br. Med. J. 1, 353-355.

8. Coleman, M. S., Greenwood, M. F., Hutton, J. J., Holland, P., Lampkin, B., Krill, C. \& Kastelic, J. E. (1978) Blood $52,1125-1131$.

9. Piras. M. A., Gakis, C., Badroni, M. \& Andreoni, G. (1978) Br. Med. J. 2, 1751-1752.
10. Hankiewicz, J. \& Koterwa, A. (1978) Mat. Med. Pol. 3, $180-183$.

11. Blake, J. \& Berman, P. (1982) SA Med. J. 62, 19-21.

12. Ocana, I., Martinez-Vasquez, J, M., Segura, R. M., Fernandez-de Sevilla, T. \& Capdevila, J. A.

a) (1983) Chest $84,51-53$.

b) (1984) Chest $86,273-274$.

13. Petterson, $\grave{T}$., Ojala, K. \& Weber, T. H. (1984) Acta Med. Scand. 215, $299-304$.

14. Giusti, G. \& Gakis, C. (1971) Enzyme 12, 417-425.

15. Giusti, G. (1974) In: Methoden der enzymatischèn Analyse, 3rd ed., Bergmeyer, (H. U., ed.) Verlag Chemie, pp. 1134-1150.

16. Ellis, G. \& Goldberg, D. M. (1970) J. Lab. Clin. Med. 76, 507-517.

17. Petterson, T., Klockars, M. \& Weber, T. (1984) Chest 86, 273.

18. Taylor, A. (1984) Clin. Chem. 30, 499-500.

Dr. E. H. Slaats

Department of Clinical Chemistry

Onze Lieve Vrouwe Gasthuis

1e Oosterparkstraat 179

NL-1091 HA Amsterdam 